UDK: 330.101.541:338.124.4

DOI: $10.2478 /$ jcbtp-2018-0012

Journal of Central Banking Theory and Practice, 2018, 2, pp. 49-72

Received: 2 June 2017; accepted: 2 July 2017

\author{
Jovan Djuraskovic* \\ Milivoje Radovic ${ }^{* *}$ \\ Milena Radonjic Konatar ${ }^{* * *}$
}

\section{The Controversies of Modern Macroeconomic Theory in the Context of the Global Economic Crisis}

\begin{abstract}
The aim of this paper is to analyze controversies of modern macroeconomic theories in the period of the global economic crisis. Ideas, disagreement and similarities between the most important theories in relation to state intervention and anti-crisis economic policy are presented. The topical research has found a connection between the roots of the global economic crisis and the paradigm of new liberal theories. The crisis has confirmed that the idea of selfregulation in the private sector is untenable in practice. In times of crisis, the leading theoretical framework in economic policy is reexamined. Rules-based monetary and fiscal policies are replaced by discretionary decision-making. In the world economies affected by the crisis, anti-Keynesian cyclical measures of monetary and fiscal policies were implemented. A comprehensive and unequivocal reaffirmation of Keynesianism in anti-crisis policies has confirmed the assumption of the circularity of economic theories. Central banks quickly reduced their key interest rates and increased their money supply. Fiscal authorities implemented expansive stimulus programs. When creating a new macroeconomic paradigm, market imperfection must be taken into account as well as a limited range of government economic policies.
\end{abstract}

Key words: economic crisis, economic theory, monetary policy, fiscal policy.

JEL classification: E32, B22, E52, E62.
${ }^{*}$ Faculty of Economics

University of Montenegro,

Podgorica, Montenegro

E-mail:

jovandj@ac.me

${ }^{* *}$ Faculty of Economics

University of Montenegro,

Podgorica, Montenegro

E-mail:

rmico@ac.me

${ }^{* * *}$ Faculty of Economics

University of Montenegro,

Podgorica, Montenegro

E-mail:

milena87@t-com.me 


\section{Introduction}

Economic crises are stumbling blocks for the adopted intellectual framework, but also a chance for a (r)evolution of new concepts and ideas. While in practice it has destructive effects and real consequences, in theory, a crisis is an inspiration and a valuable experiment against which to test the validity of economic analysis and scientific research. This is confirmed by a very fruitful period of economic theory development after the Great Depression of the 1930s. In the crisis, economic science underwent a huge progress. Macroeconomics was created. (Dimitrijević \& Fabris, 2009, p. 194)

Crises are also periods when economic theory is more engaged in analysing economic cycles of conjuncture. However, when the economy starts growing again - in periods of expansion, this topic loses its relevance and becomes unreasonably neglected. This is confirmed by the views of prominent economists, first and foremost, those of Robert Lucas (2003) who points out that the economic cycle is no longer an important topic and that economists should shift their attention towards technological progress and long-term economic growth. In the presidential address of the American Economic Association, on January 4, 2003, Lucas stated: "Its central problem of depression prevention has been solved, for all practical purposes, and has been effectively resolved for many decades". One year later, Professor Ben Bernanke, who would later become president of the Fed Governing Council, pointed out that modern macroeconomic policy had solved the problem of cyclical fluctuations or mitigated the fluctuations to such an extent that it became meaningless to treat the issue as a matter of the uttermost significance (Krugman, 2010, p. 9).

Taking into account a considerable reserve on the part of academic economists in the pre-crisis period, a criticism of economic theory in the context of the global economic crisis seems quite justified. The theory did not give many answers. Krugman (2011) states that macroeconomics has entered a dark age, in which a large part of the profession has lost all its former knowledge and, in order to solve the problem, it is sociologists who may need to be consulted on the matter rather than economists.

The contribution of the contemporary economic crisis to the development of economic theory seems to be unclear. The following questions proved themselves important in the context: To what extent is it possible to consolidate various economic theories in present conditions. Is there a possibility of consensus? Or is it that a crisis is an event that widens the gaps between the extremes even further? 
Academic economists, macroeconomists and theorists have had reasoned debate on the causes of the global economic crisis. Some believe the crisis raised doubts in the self-regulating market mechanism and market efficiency, undermining the dominance of the mainstream neoliberal theory. Krugman (2011) attributes the causes of the crises to a blind belief in the efficient market theory and real business cycle theory. Stiglitz $(2009 ; 2010)$ speaks of market fundamentalism that has led to moral bankruptcy, especially in the financial sector. Market liberalization and erroneous organizational and individual incentives led to a failure in capital allocation and created systemic risk. The global financial crisis has shown that the concept of self-regulation in the financial market becomes meaningless.

The proponents of neoliberal theories do not consider deregulation, as one of the intrinsic characteristics of modern liberal capitalism, to be the cause of the global economic crisis. They see the causes in the erroneous decisions of economic policy makers. First of all, the US Fed was slow in tightening measures of monetary policy, which was overly explosive before the onset of the crisis (Schwartz, 2009; Meltzer, 2009). Therefore, state intervention measures were to blame for the crisis.

As regards the mitigation of the consequences of the economic crisis, theoretical debates are even more intense. There is a disagreement about anti-crisis policies. New liberal theories are based on the assumption of an inherently stable private sector. The role of the state in the economy is marginalized, and the government's actions are reduced to the policy of balancing the budget. Accordingly, a savings policy is what is recommended to the government in times of crisis, rather than a fiscal stimulus policy. On the other hand, Keynesian theory requires a reduction in central bank interest rates to stimulate spending and investment. In addition to expansionary monetary policy, it is necessary to create an anti-cyclical (expansionary) fiscal policy, which implies an expected growth of the budget deficit. In the spirit of contemporary politics, governments are in a position to capitalize on their potential and intervene more into the market economy, with the aim of fostering employment in the areas of renewable energy sources, energy efficiency, new technologies, etc. (Custers, 2010, p.173).

The paper will first explain the basic disagreements and similarities in macroeconomic theories and then proceed to the central debate between Keynesian economics and monetarist economics that is a distinctive feature of the modern economic thought. The global economic crisis will be examined against the causes that generated it, that is, the leading macroeconomic paradigms that dominantly supported the pre-crisis development of economic events. A comparative analysis of the anti-crisis economic policy (monetary and fiscal policies) in the world 's leading economies will follow, offering clear implications for the development of economic theory. 


\section{Disagreements and similarities in macroeconomic debates}

Considering the progress of macroeconomic theory in the 20th century, Blanchard (2000) discusses three different periods of development:

- An epoch of exploration - pre-1940 (a coherent scientific framework had just started being built - until then there had been monetary theory on one hand, and the theory of business cycles on the other);

- An epoch of consolidation - 1940-1980 (the period in which an integral framework was developed, ranging from the IS-LM model to the dynamic general equilibrium models - used to clarify the role of shocks in economic fluctuations);

- A new epoch of exploration - post-1980 (the emergence of the Keynesian economy and the classical theory of real business cycles; imperfections in macroeconomics are considered from the relevance of nominal earnings to asymmetric information and market failures).

At the end of the second and during the third epoch of the evolution of modern macroeconomics, the debate between the new liberals and the Keynesians grew stronger. In this debate, each school gave its own contribution that can be classified as orthodox (the orthodox Keynesian school and the orthodox monetarist school), new (New Classical Macroeconomics, the school of real business cycles and the new Keynesian school) or radical (Post- Keynesian economics and Austrian economics). In this regard, the period of macroeconomics development was characterized by the following processes: Keynesian revolution, monetarist counterrevolution, new classical revolution and the "struggle" between the new Keynesians and the new classical economists. (Ješić, 2017, p. 169) The real question is - did these processes bridge or widen the gap between the theoretical extremes and to what extent? Is it possible to have a consensus on important economic issues or are the decades-long disputes between macroeconomists still a reality today? It should be borne in mind that theories developed not only through affirmation of the fundamental starting points, but also in large part through constructive criticism. And it was self-criticism that created opportunities for the rival concepts to get closer and reach some agreements in certain segments. In that sense, Snowdon and Vane (2006) presented an interesting claim that the new Keynesian economy could also be called the new monetarist economy due to its synthesis of some of the key elements of the monetarist school and the new classical macroeconomics. Table 1 illustrates the basic characteristics of macroeconomic schools, starting from orthodox over new schools to the radical ones. There is no doubt that opinions on a number of topics match to a significant degree. This, in fact, indicates that the line of separation between the theories has 
become rather blurred in practice. In other words, the emphasis on differences among the schools is often exaggerated.

Table 1: Debates in macroeconomic theories

\begin{tabular}{|c|c|c|c|c|c|c|c|}
\hline $\begin{array}{c}\text { Schools of } \\
\text { macroeconomics }\end{array}$ & $\begin{array}{c}\text { Dominant } \\
\text { source of } \\
\text { instability }\end{array}$ & Expectations & $\begin{array}{l}\text { Price/wage } \\
\text { adjustment }\end{array}$ & $\begin{array}{c}\text { Market } \\
\text { adjustment }\end{array}$ & $\begin{array}{l}\text { Notion of } \\
\text { equilibrium }\end{array}$ & $\begin{array}{l}\text { Dominant time } \\
\text { frame }\end{array}$ & $\begin{array}{l}\text { Rules v. } \\
\text { discretion }\end{array}$ \\
\hline $\begin{array}{l}\text { Orthodox } \\
\text { Keynesian }\end{array}$ & $\begin{array}{l}\text { Fluctuations } \\
\text { in } \\
\text { autonomous } \\
\text { expenditure }\end{array}$ & Adaptive & $\begin{array}{l}\text { Emphasis } \\
\text { on nominal } \\
\text { wage } \\
\text { rigidity }\end{array}$ & Weak & $\begin{array}{l}\text { State of rest } \\
\text { probably } \\
\text { below full } \\
\text { employment }\end{array}$ & Short & Discretion \\
\hline $\begin{array}{l}\text { Orthodox } \\
\text { monetarist }\end{array}$ & $\begin{array}{l}\text { Monetary } \\
\text { disturbances }\end{array}$ & Adaptive & Flexible & Strong & $\begin{array}{l}\text { Market clearing } \\
\text { at natural rate }\end{array}$ & $\begin{array}{l}\text { Short and } \\
\text { long }\end{array}$ & Rules \\
\hline New classical & $\begin{array}{l}\text { Monetary } \\
\text { disturbances }\end{array}$ & Rational & $\begin{array}{l}\text { Perfectly } \\
\text { flexible }\end{array}$ & $\begin{array}{l}\text { Very } \\
\text { strong }\end{array}$ & $\begin{array}{l}\text { Market clearing } \\
\text { at natural rate }\end{array}$ & Long $=$ short & Rules \\
\hline $\begin{array}{l}\text { Real business } \\
\text { cycle }\end{array}$ & $\begin{array}{l}\text { Supply shocks } \\
\text { (mainly } \\
\text { technological) }\end{array}$ & Rational & $\begin{array}{l}\text { Perfectly } \\
\text { flexible }\end{array}$ & $\begin{array}{l}\text { Very } \\
\text { strong }\end{array}$ & $\begin{array}{l}\text { Market clearing } \\
\text { at moving } \\
\text { natural rate }\end{array}$ & Long = short & Rules \\
\hline New Keynesian & $\begin{array}{l}\text { Demand and } \\
\text { supply shocks } \\
\text { (eclectic) }\end{array}$ & Rational & $\begin{array}{l}\text { Emphasis } \\
\text { on price } \\
\text { rigidities }\end{array}$ & Slow & $\begin{array}{l}\text { Consistent with } \\
\text { involuntary } \\
\text { unemployment }\end{array}$ & $\begin{array}{l}\text { Predominantly } \\
\text { short }\end{array}$ & $\begin{array}{l}\text { Constrained } \\
\text { discretion }\end{array}$ \\
\hline Post Keynesian & $\begin{array}{l}\text { Fluctuation in } \\
\text { autonomous } \\
\text { expenditure }\end{array}$ & Reasonable & Sticky & $\begin{array}{l}\text { Very } \\
\text { weak }\end{array}$ & $\begin{array}{l}\text { State of rest } \\
\text { probably } \\
\text { below full } \\
\text { employment }\end{array}$ & Short & Discretion \\
\hline Austrian & $\begin{array}{l}\text { Monetary } \\
\text { disturbances }\end{array}$ & Reasonable & Flexible & Strong & $\begin{array}{l}\text { Tendency } \\
\text { forwards }\end{array}$ & $\begin{array}{l}\text { Short and } \\
\text { long }\end{array}$ & Rules \\
\hline
\end{tabular}

Source: Snowdon, B., Vane, H. R. (2006), Modern macroeconomics - Its Origins, Development and Current State, Cheltenham: Edward Elgar, p.702.

In the context of the global economic crisis, two important dilemmas in macroeconomic debates seem to have gained particular importance: should economic policy be active or passive and, accordingly, should policy-making be rules-based or discretionary? Policy makers can use stabilization measures to smooth economic fluctuations. However, should they? Those macroeconomists who advocate an active economic policy do not see why society should suffer due to cyclical economic activity. After all, they believe that the market adjusts slowly, i.e., that it is not a perfect "self-regulating" mechanism.

Monetary and fiscal policies, for this reason, must stimulate aggregate demand in times of crisis, and dissuade it in times of expansion. A somewhat rigid attitude of the "older" Keynesians to fine tuning was replaced by the postulate of the new Keynesian school that stabilization policy should be used only in case of large recessions, while small fluctuations should be left to the market self-regulation (Snowdon et al., 2006, p.445). Contrary to these views, representatives of new liberal theories believe that the effects of economic policy must be awaited for a 
long time, which creates a problem of a time gap and a potential danger that the measures have counterproductive effects due to poor timing. For these reasons, they are in favour of a passive economic policy.

Complementary to the first dilemma, an answer to the second question- should economic policy rely on rules or discretion? - is given. Supporters of an active economic policy are in favour of discretionary rights. The reason for this is the policy flexibility. The effectiveness of instruments is greater if they can adapt to new circumstances. Measures must be constructed in response to economic shocks. And, it is precisely because of the constant uncertainty in which modern economy develops that it is not possible to design universal rules of monetary and fiscal policies. Simply put, there is no consensus on what a "good" rule could be. Macroeconomists who, in turn, advocate for clear rules in implementing economic policies point to the dangers of incompetence and abuse of power. Melcer (2012) notes that it is necessary to abandon discretionary policy and adhere to a clear rule. He states that this strategy worked perfectly with the Taylor Rule in the period of low inflation and stable growth (1985-2003). The moment when it is estimated that it is rational to abandon the rule, monetary authorities must announce the decision and take responsibility. Often, discretionary measures can have political goals whose implementation further stimulates the fluctuation of economic activity (political conjuncture cycles in election periods). Therefore, institutions' independence is directly proportional to the credibility of their decisions. (Jakšić et al., 2006, p.70; Jakšić et al. 2018, p. 5; Angelovska Bezhoska, 2016, p. 36) If these decisions are not consistent, discretion will not yield good results.

The effectiveness of discretionary fiscal policy was called into question by Reinhart and Rogoff in their 2010 study. Based on data on economic growth and public debt in 44 countries over a period of 200 years, the authors come to the conclusion that the relationship between public debt and real GDP is weak in those situations where public debt is below the 90\%-of-GDP threshold. When public debt is above $90 \%$ of GDP, average growth rates fall by more than $1 \%$. When external debt reaches $60 \%$ of GDP, annual growth decreases by about $2 \%$, and for higher levels of debt, growth rates are reduced by half. Trends were shown to be very similar in both developed and emerging markets. The results of this study have become an alibi of a kind for the creation of austerity measures in the EU and "belt-tightening" in the United States. It has sparked a very significant debate among macroeconomists. However, the relevance of the study was questioned after the data audit and the new results of April 2013. A group of US economists came to the conclusion that the 2010 study showed serious shortcomings because it had neglected available data and unprofessionally presented stylized facts. New 
research supported the Keynesian recommendation of expansionary fiscal policy. Namely, the average growth rate of real GDP for the countries whose public debt is over $90 \%$ of GDP is $2.2 \%$ and not $-0.1 \%$, as was claimed by Reinhart and Rogoff. In addition, the average real growth rate when public debt is over $90 \%$ of GDP does not differ significantly from the case when the debt is below this value (Herndon et al., 2013).

\section{The Keynesian-monetarist controversy}

The Keynesian vs. monetarist debate dates back to the Great Depression. Bearing in mind the devastating consequences of the 1930s crisis in developed capitalist economies and the weakness of the concept of a self-regulating market, an affirmation of state interventionism was inevitable. Robert Skidelsky points out that Keynes' ideas were recognized as a sort of paving the "third" way between two extremes, liberal conservatism and socialism (DeLong, 2002, p.158). A disbelief in the inherent stability of the private sector was the basis for creating an anticompetitive macroeconomic policy whose task was to alleviate the undesirable effects of short-term economic fluctuations. Keynesian interventionism and active discretionary economic policy oppose the monetarist philosophy of noninterventionism and policy making based on pre-defined rules.

The concept of aggregate demand management occupies the central place in the Keynesian model of state intervention. The Keynesians believed that in the period of an economic crisis, due to insufficient aggregate demand that generates production and employment and since the market is not a perfect self-regulatory mechanism, a decisive state intervention is necessary. One should not forget that during the Great Depression in the US economy, consumer spending and private investment experienced a double-digit decline (spending fell by $18 \%$ and gross investment dropped by as much as $98 \%$ ). Due to poor coordination at the level of developed economies, general protectionism of foreign trade was introduced and, thus, export as an "external" part of aggregate demand also experienced a contraction. For these reasons, Keynesians felt that public consumption (G) was the only component of demand that could generate growth. The formulation of relevant recommendations for Keynesian stabilization policy depended on the fundamental formulation of the factors of each of the individual components of aggregate demand. Here is a simple mathematical interpretation of the functions of consumption, investment and public expenditure (Keynesian model of a closed economy) (Babić, 2007, p.252): 


\begin{tabular}{|c|c|c|}
\hline $\begin{array}{c}C=f\left(Y_{d}\right) \\
Y_{d}=Y-T+T R \\
C=\alpha+\beta Y_{d}\end{array}$ & $\mathrm{I}=\mathrm{f}(\mathrm{r}, \mathrm{Y})$ & $\begin{array}{c}\mathrm{G}=\mathrm{T} ; \mathrm{G}<\mathrm{T} ; \mathrm{G}>\mathrm{T} \\
\mathrm{T}=\mathrm{T}_{\mathrm{a}}+\mathrm{tY}\end{array}$ \\
\hline $\begin{array}{l}\beta=\frac{\Delta C}{\Delta Y_{d}} \\
0<\beta<1\end{array}$ & $\frac{\Delta 1}{\Delta \mathrm{I}}=\frac{1}{1-\beta}$ & $\frac{1}{1-\beta}>\frac{1}{1-\beta+\beta t}$ \\
\hline
\end{tabular}

Consumer spending $(\mathrm{C})$ is a function of disposable income (Yd). Disposable income is that part of income $(\mathrm{Y})$ that remains after tax deduction $(\mathrm{T})$ and the increase by the amount of transfer payments (TR). The basic function of consumption assumes the existence of two components. The first is autonomous consumption $(\alpha)$ that does not depend on domestic income $(Y)$. The second element of the equation ( $\beta \mathrm{Yd}$ ) shows how much of disposable income goes to consumption. Both components are positively correlated with consumer spending. Investments are a function of (real) interest rate (r) and domestic income growth (Y). Growth in real interest rates reduces investment, while there is a positive correlation between investment and production growth.

The central place of the Keynesian analysis is the multiplication process. The simplest multiplier, the investment multiplier is $\frac{1}{1-\beta}$. It points to the important conclusion of the Keynesian concept that each new unit of demand increases income (production) by more than one unit, that is, by the amount of the multiplier. The third component of aggregate demand, public expenditure $(G)$, is directly related to taxes. In a balanced budget, revenues are equal to expenditures, i.e., $\mathrm{T}=\mathrm{G}$. Therefore, it was also important to express the tax function $\mathrm{T}=\mathrm{T}_{\mathrm{a}}+\mathrm{tY}$, where the sum of taxes $T_{a}$ is independent of the size of income (e.g. property tax, inheritance tax, etc.) and $\mathrm{tY}$ part of the tax that depends on the domestic product (value added tax). It is important to point out that the increase in taxes reduces disposable income $\left(\mathrm{Y}_{\mathrm{d}}\right)$ and the multiplier which after the introduction of the component $G$ into the model becomes $\frac{1}{1-\beta+\beta t}$. Thus, taxes $(T)$ decrease multiplication and represent an outflow of money from business flows. On the other hand, investments (I) and government consumption (G), as well as transfers (TR), positively affect the growth of aggregate demand and thus the multiplication process as well.

In a crisis, solutions are sought in anti-cyclical economic policies. According to Keynesians, expansionary fiscal policy is of primary importance (only later did they mitigate this attitude), and solutions need to be sought in government 
investment (public works). This means that in times of crisis, the goal of balancing the budget is abandoned.

Graph 1 shows the effects of expansionary fiscal policy, i.e. increasing public expenditure and/or reducing taxes. In the case of a fully elastic LM curve (the case of Kaynes' liquidity trap), fiscal policy stimulus measures will cause a significant increase in domestic product from $\mathrm{Y}_{0}$ to $\mathrm{Y}_{1}$ (shifting of the IS curve to the right, from IS to IS'). The increase in production is equal to the product of the multiplier and the growth of government consumption $\Delta \mathrm{G}$.

It is important to note that in this Keynesian case, the growth of public expenditure (through borrowing rather than growth of taxes) does not cause interest rate growth, but only the growth of domestic product. In contrast to Keynesians, new classical economists start with the assumption of full employment (their LM curve is vertical), and increasing public expenditure leads to the shifting of the $\mathrm{IS}_{3}$ curve to the $\mathrm{IS}_{3}$ position, which results only in an increase in interest rates without affecting real output $\left(\mathrm{Y}_{4}\right)$. Therefore, in their case, an expansionary fiscal policy is ineffective. In the area between these two extremes, when the LM curve is rising (as in the Hicks model), an increase in public expenditure leads to shifting the curve from the IS ${ }_{2}$ position to IS ${ }_{2}$, which affects the growth of interest rates and domestic product (from $\mathrm{Y}_{2}$ to $\mathrm{Y}_{3}$ ). The size of both increases depends on the slope (elasticity) of the LM curve, which ultimately determines the success of expansionary fiscal policy. If it is horizontal or flat, as the Keynesians argued, fiscal policy will have very positive effects on production and interest rate growth. It is due to the results of this analysis that Keynesians opted for deficit policy.

Figure 1: Effects of anticyclical economic policy in the IS-LM model
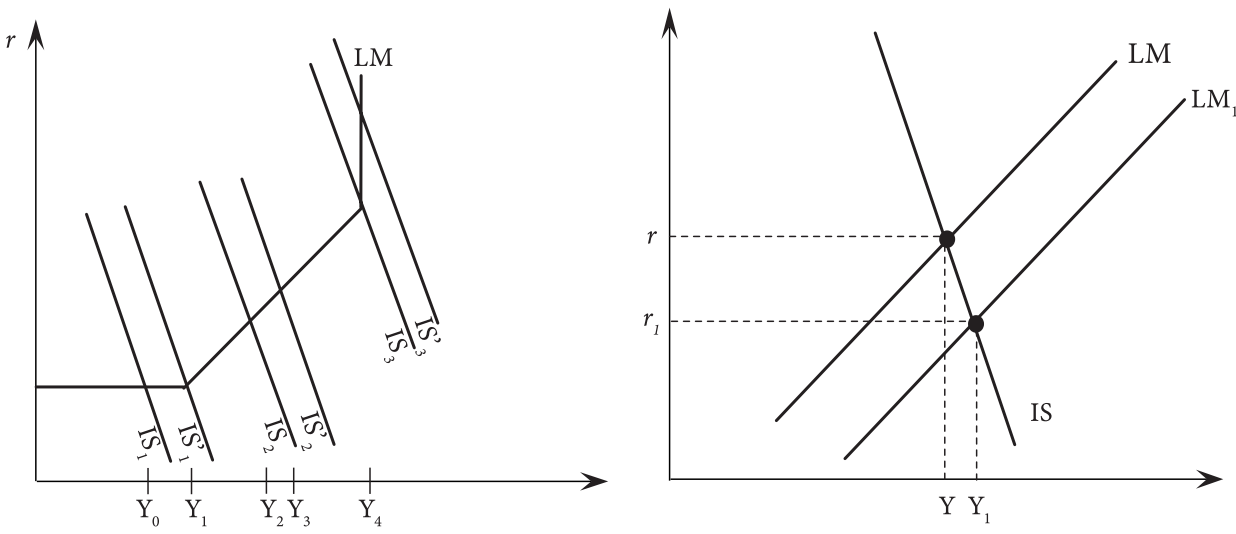
The theoretical disagreement between Keynesians and monetarists was due to different views on monetary policy. Keynesians emphasized the primacy of interest rates, and monetarists the ultimate role of money supply. Monetary policy, according to Keynesians, must be expansionary. Interest rates (r) must be low, so as to stimulate investment (I). However, this is not a sufficient condition for the growth of aggregate demand. The practice back in 1930s confirmed this. The extremely low interest rates did not attract investors. Relying on an inelastic investment demand, Keynesians attributed secondary importance to monetary policy. In their LM model, the curve is rather flat (in an extreme Keynesian case it is horizontal - perfectly elastic). This means that the growth of money supply shifts the LM curve to the right and leads to a fall in interest rates from $r$ to rl. However, as investments react very little to this change, the growth of domestic product is proportionally lower than the fall in interest rates (from Y to Y1).

Responding to the Keynesian claim on the impotence of monetary policy, monetarists pointed out that the reduction in interest rates is not a sufficient condition for expansionary monetary and credit policies in crisis. It is suffice to recall the Fed's policy in the Great Depression, when the nominal discount rate during 1932 was $2.5 \%$, but due to the deflation rate of $10 \%$, the ex-post real discount rate rose to $12.5 \%$. The insensitivity of investment to the decrease in interest rates was a confirmation to Keynesians who later concluded in their model that the IS curve was fairly inelastic, and the monetary policy impotent in the fight against economic depression. On the other hand, monetarists believed that the problem of the Fed's strategy was the insufficient use of open market operations as the most essential instrument of monetary policy (Brunner et al., 1968, p.347). Monetarists do not doubt the dominance of monetary policy over fiscal policy. Monetary policy needs to be created according to a clear rule, which implies a (gradual) growth of money supply in accordance with the growth of GNP (gross national product). In an interview, Milton Friedman described the relationship between fiscal and monetary policies on the example of the Great Depression: "There is absolutely nothing to be done about fiscal policy to compensate for a drop in money supply by 1/3" (Congdon, 2011, p. 64). An additional argument is the problem of time lag in the functioning of an active economic policy. Instead of being a solution, state intervention is often a problem. Therefore, according to monetarists, discretionary fiscal measures must be avoided, while automatic stabilizers are the only effective instrument that will not contribute to economic instability. 


\section{The global economic crisis - an error in the model or the wrong model?}

After the Great Depression and the emergence of the first Keynesian views, the belief grew stronger that unregulated financial markets are inherently unstable, subject to fraud and manipulation by insiders and with a capacity to shake up the economy, leading to crisis and socio-political hardship. In order to protect the economy and the state from these threats, the US government in the Roosevelt administration period, created a rigorous financial regulatory system, which effectively operated until the 1970s. Nevertheless, the economic and financial turbulence during the 1970 s and early 1980s led to a paradigm change and a return to neoliberal ideas. The efficient financial market theory and the new classical macroconcept replaced the Keynesian economic policy. The existing system of strict financial regulation was reconstructed into a process of radical deregulation, which opened up a space for transition to globally integrated neoliberal capitalism.

In the period of domination of new classical theories, a new financial architecture was created. There was a rapid development of financial innovations which became complex and incomprehensible, and in a crisis, dangerous and illiquid. On the other hand, the system was based on insufficient regulation of commercial banks, even more mild regulation of investment banks and very low and almost nonexistent regulation of the shadow banking system. Towards further deregulation of the financial system in the late 1990s, the strict regulations implemented by adopting the 1933 Glass-Steagal Act were formally abolished. Namely, by passing the 1999 Financial Services Modernization Act, the barriers between commercial banking and securities transactions were removed. This enabled the creation of a very complicated system of connections between financial entities. The extent of this interdependence and the activity of the financial entities were beyond the scope of state control (Štiblar, 2009, p. 109). In addition, investment banks were allowed to use their own mathematical models to assess portfolio risks and thus determine the appropriate level of compulsory capital. This led to an increase in risky business in the financial sector.

The immediate causes of the global economic crisis are closely linked to the loan explosion on the US real estate market and the subprime mortgagebacked securitization. Traditional forms of business in commercial banking were abandoned. Issuing mortgage loans without a receipt of income, business or assets (NINJA Loan - no income, no jobs or assets) became a general practice. Fixed interest rates on a 30-year mortgage loan in the early 1980 s exceeded $18 \%$, only to fall below $6 \%$ in the mid-2000s. Even cheaper was a variable interest rate 
arrangement that had been in the federal "use" since 1984. In the absence of regulation and adequate state control, credit standards loosened progressively. Loans were granted in a way that could not be imagined under traditional banking conditions.

The traditional "borrow and keep" model of lending, in which banks retained issued loans in their own balance sheets, was replaced by a new "borrow and distribute" model. By creating liquid securities based on subprime mortgages, an enormous inflow of capital was secured, which was again placed on the real estate market, which additionally increased the credit and housing bubble. In addition, it is quite clear that in the process of securitization, the risk did not decrease, but was only dispersed and transferred to entities that were least able to understand it (Štiblar, 2009, p.87). Actually, the risk became less obvious, precisely due to the lack of transparency that characterizes the shadow banking system. In this complicated role distribution in the process of securitization of subprime mortgage loans, a moral hazard occurred. It is clear that in such circumstances, the classical economics principle of self-regulation and inherent stability of the private sector is not sustainable.

These circumstances created uncertainties in the U.S. and global financial systems, and long-time critics of the Fed management were satisfied with Congressman Alan Greenspan's statement as of October 2008, when he admitted a "mistake in the model", based on which the financial system operates. "I made a mistake in presuming that the self-interest of organisations, specifically banks and others, was such that they were best capable of protecting their own shareholders and equity in the firms" (The Guardian, 2008). In “The Crisis” (2010), Greenspan pointed out that the Federal Reserve never fully understood the seriousness of the risks that would occur later.

Bearing in mind the repercussions of the pre-crisis model, economic theory has faced an important dilemma: is there a mistake in the model or is the model itself wrong? In other words, the current crisis opens up the possibilities for the end of neoliberalism, but it could instead result in its remaking (Cahill, 2011, p.492).

\section{Theoretical basis of anti-crisis economic policy}

The long-held views of the new classical concepts became a kind of stumbling block in the fight against the global economic crisis. Neoliberal theories proved to be inconsistent (Khasbulatov, 2015, p. 23). Additional stabilization measures were necessary. They involved active interventionism and anti-cyclical economic 
policy. Both monetary and fiscal policies became expansionary with elements of discretionary decision-making. The anti-crisis economic policy was created in accordance with Keynesian economics.

The global economic crisis called for global interventionism. It decisively influenced a more active action of the G20. In a declaration adopted at the first G20 summit in Washington (November, 2008), a synchronized implementation was agreed of both expansionary fiscal measures to stimulate domestic demand and expansionary monetary measures to stabilize the financial system and ensure the necessary liquidity. It was agreed at the summit that no country should use any protectionist measures in foreign trade in the following 12 months. The importance of the decision was additionally emphasized by the fact that the G20 economies accounted for almost $90 \%$ of the world GDP and $80 \%$ of the global trade.

The remainder of the paper presents the key anti-crisis measures of monetary and fiscal authorities in the most important world economies, members of the G20.

\subsection{Anti-crisis monetary policy}

In the United States, the Great Depression lessons were taken seriously. The modern anti-crisis policy of the Fed can hardly be called indecisive. After a series of reductions, as shown in the following figure, the Fed reduced the target federal funds rate to $3 \%$ by February 2008. By May the same year, the rate was $2 \%$, and in December 2008, it reached a record low value of 0-0.25\%. The Fed stimulated lending activity at a time when it was certain that financial institutions would fall into a liquidity trap (Djuraskovic et al., 2016, p.16). The decision to reduce the usual gap between the discount rate and the federal funds rate (from 100 to 25 basis points), with the extension of the deadline for repaying the Fed loan from overnight to 90 days, speaks in favour of a more flexible credit policy.

In addition to the very serious problem of insolvency, monetary authorities faced a dramatic decline in the monetary multiplier just as they did in the 1930s. It decreased by more

Figure 2: Fed funds rate and discount rate

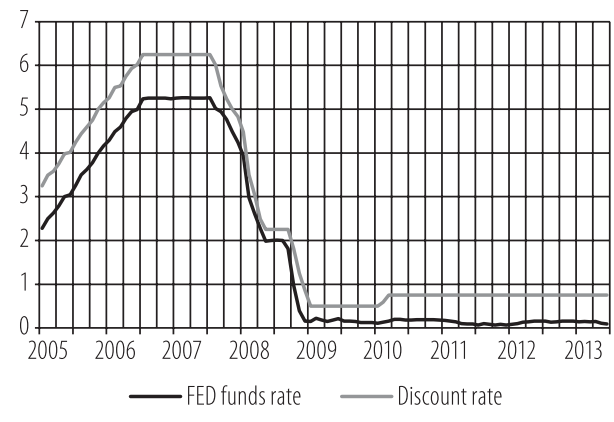

Source: Federal Reserve System, 2013. 
than $40 \%$ in the second half of 2008. Errors from the period of Great Depression were avoided, as the Fed decided to step up expansionary measures, which soon reflected on the Central Bank balance. The total value of Fed assets increased from \$ 894 billion at the end of 2007 to \$ 2,237 billion in December 2009 (Thomas, 2011, p.161). The initial growth of the monetary base during 2008 was the result of the Fed's extreme lending to the financial industry. At the end of 2007, next to the loans section in the Fed's balance sheet was the number of $\$ 4.5$ billion, and only a year later, the value of approved loans, on various bases, amounted to $\$ 1,700$ billion (Lawrence, 2009, p.121). In addition, the usual purchase of long-term government bonds, as well as bonds of federal agencies, was intensified, which further increased the supply of money through the most important US monetary policy instrument - open market operations. The Fed did not allow a decrease in money supply, which was the biggest criticism to its policy in the period of Great Depression. The non-conventional policy of quantitative and qualitative easing was intensively applied.

Observing the changes in the key ECB interest rates, a similarity with the monetary policy of the Fed could be noticed, which, before the crisis, was also characterized by the rise in key interest rates. Following the bankruptcy of Lehman Brothers in mid-September 2008, the ECB reacted by reducing the key interest rates to counter the liquidity problem of financial institutions. In January 2009, after four reductions, the key interest rates recorded the value equal to that of June 2003.

Figure 3: Key ECB interest rates, changes since 1999

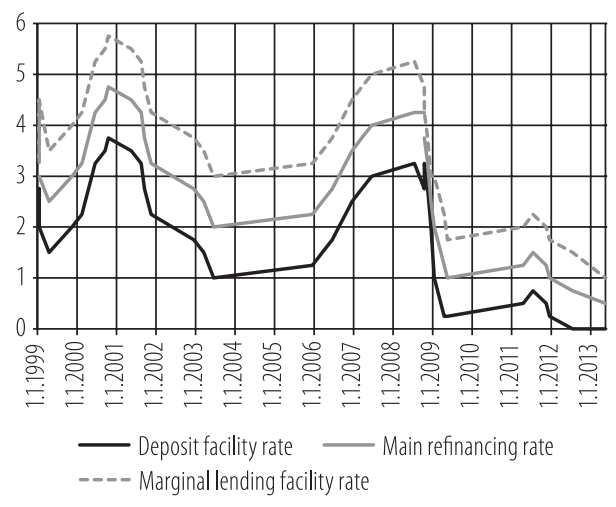

Source: European Central Bank, 2013.
Increased credit support, especially to long-term refinancing, positively influenced the liquidity of financial institutions. The ECB strengthened its role as an intermediary between financial institutions in the euro area, resulting in quite an intense decline in money market activities and an expansion of the ECB's balance (from 1.2 trillion euros in August 2007 to 1.85 trillion euros in August 2008).

In the UK, the Northern Rock crisis marked the beginning of state intervention in the financial market. In October 2007, a decision was made to guarantee all bank deposits up to 
$£ 35,000$ (in relation to the $£ 2,000$ limit) and a year later the limit was increased to $£ 50,000$. In April 2008, the Bank of England adopted the Special Liquidity Scheme (SLS), enabling banks to temporarily exchange high-quality mortgage and other securities for treasury bills, with a maturity of up to 3 years (Goddard et al., 2009, p. 363). The program was $£ 50$ billion worth and it was officially abolished on January 30, 2012. From September 2008 to March 2009, the Bank of England lowered the Bank rate from 5\% to $0.5 \%$. However, the basis rate instrument did not function as it would under usual circumstances. Interbank lending rates remained high, while the amount of transactions was reduced. On the other hand, the decline in inflation (from $3.6 \%$ in 2008 to $2.2 \%$ in 2009) made real interest rates negative. It became clear that the low interest rate policy would not suffice. That is why monetary authorities, in agreement with the Ministry of Finance of the UK launched a quantitative easing policy, similar to that in the United States.

In response to the effects of the global economic crisis, the Bank of Japan decided to cut its interest rates rapidly. Thus, the target interest rate on overnight loans decreased from $0.5 \%$ to $0.3 \%$ at the end of October 2008 , i.e. to $0.1 \%$ two months later. In the same period, the basis rate for loans fell from $0.5 \%$ to $0.3 \%$ (Vollmer et al., 2012, p.63). At the end of 2008, the BoJ launched a credit easing policy. Since the interest rate on non-standard overnight loans was already at $0.1 \%$, its further reduction was almost impossible. Thus, the BoJ decided to fully expand and increase the volume of government bond purchases. In addition, the number of securities the BoJ accepted as collateral (bonds, commercial bills, loan agreements, etc.) grew continually.

Faced with dramatic global challenges in the second half of 2008, the Bank of Russia, had to implement some unplanned and unusual measures. Double-digit inflation and outflow of capital were the reasons for the increase in interest rates in 2008. The refinancing rate (the Central Bank's basis rate) did not begin to decline continuously (by 50 basis points) until April 2009. In the second half of 2010 , it reached the value of $7.75 \%$. When the 2009 monetary policy was created, inflationary expectations were more favourable and the foreign exchange market stabilized. In the period April-December, the Central Bank's key interest rates changed ten times, with a final decrease of 1.5-4.5\% depending on the monetary instrument, which led to a further decline in interest rates on corporate loans from $17.1 \%$ in January to $13.4 \%$ in December (The Central Bank of the Russian Federation, 2010, p.64). This met the requirement of the Keynesian concept of interest rate cuts during a fall in economic activity. 
In September 2008, China's Central Bank made a shift in monetary policy. The bad news from the global financial market and the spreading of the economic crisis led to the abandonment of restrictive and the creation of expansionary measures of monetary policy. The Bank decided to reduce the reference rate on loans to financial institutions from $7.47 \%$ to $7.20 \%$. In October, the reference rate on one-year deposit declined from $4.14 \%$ to $3.87 \%$. At the end of the year, after several reductions, the reference interest rate on loans to financial institutions was $5.31 \%$, and on annual deposits $2.25 \%$. By the end of the year, the Central Bank reduced its one-year interest rate on loans to financial institutions from $4.68 \%$ to $3.33 \%$, and its discount rates from $4.32 \%$ to $1.80 \%$. In addition, the rate on obligatory reserves decreased from $1.89 \%$ to $1.62 \%$, and the rate on excess reserves of deposit institutions from $0.99 \%$ to $0.72 \%$ (The People's Bank of China, 2013). Anti-cyclical monetary policy measures contributed to a significant increase in bank lending. Loans in domestic currency increased by 7.4 trillion yuan in the first half of 2009, which was three times higher than in the first half of the previous year.

\subsection{Anti-crisis fiscal policy}

Monetary policy measures were not sufficient to counter the resulting recession. Economic policy makers implemented an anti-cyclical fiscal policy modelled on the Keynesian concept of state intervention, whether on a smaller or larger scale. Table 2 shows the most important anti-crisis fiscal measures and the volume of fiscal stimuli created in 2008/9.

In February 2008, the Economic Stimulus Act was adopted in the US which provided tax refunds to low-and middle-income households as well as tax incentives for businesses. The intention was to increase the disposable consumer income as the basic determinant of consumer spending. By July 1, 2008, more than 70 million US households received a tax return of an average of $\$ 950$. Research has shown that tax return stimulated non-durable goods consumption, with an average increase of $3.5 \%$ on a weekly basis. Unlike typical households, families with an annual income of less than $\$ 15,000$ increased non-durable goods consumption by $6 \%$ (Broda et al., 2008).

The adoption of the second fiscal stimulus (TARP) in November of the same year caused the most controversy, as this fiscal package was intended to support financial corporations. This, along with the "toxic" expansion of the Fed 's assets, justly incited a negative public reaction to the too-big-to-fail concept. More comprehensive and more contentious anti-cyclical fiscal policy measures were 
taken through the implementation of the American Recovery and Reinvestment Act (ARRA), which provided a fiscal stimulus of $\$ 787$ billion. According to the 2013 US government data, this amount was later corrected and the final stimulus reached $\$ 840$ billion. Of the total amount, $\$ 290.7$ billion was allocated to tax relief, \$255.6 billion to education, infrastructure projects and traffic, and $\$ 251.3$ billion to health care, unemployment insurance, etc.

Table 2: Anti-crisis fiscal stimuli in selected economies

\begin{tabular}{|c|c|c|c|}
\hline Country & Fiscal stimulus & Date & $\begin{array}{c}\text { Total amount } \\
\text { (in billions) }\end{array}$ \\
\hline \multirow{3}{*}{ USA } & Economic Stimulus Act & Feb/2008 & $\$ 168$ \\
\hline & Troubled Asset Relief Program & Oct/2008 & $\$ 700$ \\
\hline & American Recovery and Reinvestment Act & Feb/2009 & $\$ 787$ \\
\hline EU & European Economic Recovery Plan & $\mathrm{Nov} / 2008$ & $€ 200$ \\
\hline \multirow{3}{*}{ Germany } & Employment Pact through Increased Growth & Nov/2009 & $€ 50$ \\
\hline & Employment and Stability Pact & $\mathrm{Jan} / 2009$ & $€ 50$ \\
\hline & Accelerated Economic Growth Act & $\mathrm{Dec} / 2009$ & $€ 22$ \\
\hline France & Fiscal stimulus package & $\mathrm{Feb} / 2009$ & $€ 26.5$ \\
\hline UK & Fiscal stimulus package & Nov/2008 & $£ 20$ \\
\hline \multirow{4}{*}{ JAPAN } & Comprehensive Immediate Policy Package & Aug/2008 & $\$ 105.8$ \\
\hline & Measures to Support People's Daily Lives & Oct/2008 & $\$ 250$ \\
\hline & Immediate Policy Package to Safeguard People's Daily Lives & $\mathrm{Dec} / 2008$ & $\$ 340$ \\
\hline & Policy Package to Address Economic Crises & Apr/2009 & $\$ 574$ \\
\hline CHINA & Fiscal stimulus package & Nov/2008 & $\$ 586.68$ \\
\hline
\end{tabular}

The globalization of the financial crisis in September 2008 and its spreading to real economy required a coordinated action from the EU Member States. On November 26, 2008, the European Commission announced a plan for mitigating the effects of the financial crisis, which implied a coordinated fiscal stimulus for the EU Member States. The proposal published by the European Commission states the following: "This European Economic Recovery Plan proposes a countercyclical macro-economic response to the crisis in the form of an ambitious set of actions to support the real economy. The aim is to avoid a deep recession" (European Commission, 2008, p.6). The plan, above all, required an accelerated implementation of the fiscal stimulus in the total amount of $€ 200$ billion $(1.5 \%$ of the EU's GDP), of which 170 billion was intended for fiscal expansion in EU member states, and the remaining 30 billion was provided from EU funds. The stimulus goals were to increase the purchasing power of population, stimulate demand and strengthen consumer confidence. Consequently, governments had to use a diverse mix of economic policy instruments. This meant an increase in 
public expenditure, a reduction in taxes and contributions, the introduction of tax incentives for SMEs, etc.

Given the uneven level of economic development of EU member states, some economies were able to implement significant fiscal interventions, while in certain countries (Greece, Portugal, Italy, etc.) budget manoeuvre were insufficient for any serious anti-crisis intervention. Due to public debt crises in some economies, in 2010, the EU made a turnaround in anti-crisis policy by abandoning anticyclical measures. The adopted fiscal consolidation concept contributed to negative trends and Europe entered another recession.

In the period 2008/09, Germany implemented three fiscal stimuli. It was estimated that the overall volume of fiscal stimulus reached a value of $4 \%$ of GDP in 2008. The overall goal was to stimulate aggregate demand, primarily domestic consumption and investment. For example, the lowest tax rate on income was reduced from $15 \%$ to $14 \%$ since January 2009. Tax relief measures were followed by support for socially vulnerable groups. Social benefits for children were increased, and the fiscal stimulus provided around $€ 4$ billion at the national level for investments in infrastructure (highways, noise protection, energy restoration of buildings, etc.). For the same purpose, the $2^{\text {nd }}$ fiscal stimulus provided $€ 10$ billion for regional infrastructure projects (International Labour Organization, 2011, p.33).

In its report before the crisis onset, at the end of the first quarter of 2008, the Ministry of Finance of the United Kingdom committed to the liberal philosophy of noninterventionism. It states that " the economy is stable and resilient [...] able to cope with economic shocks quickly and with low economic costs - which has resulted in an unprecedented period of macroeconomic stability [...] and [having it all in mind] the Government is meeting its strict fiscal rules for the public finances" (HM Treasury, 2008, p.1-2) Namely, from 1997 to the end of 2008, the fiscal policy in the UK was prepared in accordance with the Code for Fiscal Stability, which implied the principle of balancing the budget over the economic cycle, with the rule that the Government could only borrow money for the purpose of investing, and not to fund current spending ("the golden rule"). The crisis led to a suspension of these rules at the end of 2008. The negative rate of economic growth caused an energetic turnaround in the creation of fiscal policy. The government set up a "temporary operating rule: to set policies to improve the cyclically-adjusted current budget each year, once the economy emerges from the downturn, so it reaches balance and debt is falling as a proportion of GDP once the global shocks have worked their way through the economy in full." (Sawyer, 2012, p.16). 
In line with the new concept, the fiscal policy response can be summarized as follows: the automatic stabilizers were permitted to operate with discretionary increases in public expenditure and temporary reductions in tax rates. In November 2008, a fiscal stimulus of $£ 20$ billion was adopted. Among other things, the stimulus meant a temporary reduction in value added tax from $17.5 \%$ to $15 \%$, starting from December of the same year. In addition, about $£ 3$ billion worth of capital spending was brought forward, primarily intended for schools, social institutions, transport infrastructure, and energy efficiency projects. In early 2009, the government adopted a Small Business Loan Guarantee Scheme worth $£ 20$ billion, with the intention of guaranteeing loans taken by small and medium-sized enterprises.

The French government was also forced to implement a strong anti-cyclical fiscal policy. At the beginning of 2009, the implementation of the general plan for the revival of the French economy began, which amounted to $€ 26.5$ billion. A broad investment activity was in the focus of an expansionary fiscal policy. The stimulus was thus divided into three segments: $€ 11.4$ billion to support private businesses, $€ 11.1$ billion for direct public investment and $€ 4$ billion for large state-owned companies in the railways, energy and postal services sectors.

Despite the chronic problem of public debt, the Japanese government implemented a vigorous expansionary fiscal policy. In less than half a year, three fiscal stimuli were adopted, for which a total of 75,000 billion yen (almost 760 billion dollars then) was allocated. Of this amount, 12,000 billion yen was for fiscal measures (budget expenditure and tax cuts), and 63,000 billion yen for financial measures (recapitalization, crediting, buying securities). In the fourth fiscal stimulus, which was to a lesser extent withdrawn, out of a total of 56,800 billion yen worth of the fiscal package (about $\$ 570$ billion), the greatest up to then allocated amount of 15,400 billion yen was intended for anti-crisis public expenditure.

The anti-cyclical fiscal policy in China was implemented using a 4 trillion yuan worth fiscal package ( $\$ 586.68$ billion), i.e. $12.5 \%$ of national 2008 GDP. In the total stimulus, the central Government participated with 1.18 trillion yuan, while other funds were secured through the inputs of local governments and state-owned banks. The stimulus was supposed to be large, fast and effective, and a 27-month deadline period set for the implementation. State-owned banks opened their spigots and 2009 witnessed a real expansion in lending (Wong, 2011, p. 58). If the structure of the expansionary fiscal policy is analysed, it becomes immediately clear that public works were the most important element of the Chinese stimulus. In 2009, almost every sector of the economy (industry, agricultural production, trade, automobile industry, etc.) was allocated from $10 \%$ 
to $40 \%$ more funds than in the previous year. On the other hand, tax relief and the abolition of administrative costs reached a value of 680 billion yuan.

\section{Conclusion}

When various interpretations of the global economic crisis are analysed, it becomes clear that systemic differences between economic theoreticians and macroeconomists still exist. Times of crisis are hardly the best times for consensus. The gap among theories deepens, and errors are sought for in someone else's yard. In a new socio-economic reality, every doctrine seeks to find its ground.

Modern economic reality confirms a very important fact - the development of economic theories is neither linear nor finite. The circularity of economic ideas and their re-actualization is what makes them different in comparison to natural sciences. Sufficient evidence that the development of theories is circular is already an unequivocal reaffirmation of the Keynesian doctrine in the modern economic policy of developed capitalist economies.

The crisis has shown that the (neo)classic assumption of the market as a selfregulating mechanism is not credible. This is best demonstrated by the intricate and vague concept of securitization in the financial sector. There was no motive for self-regulation. If that motive had existed, business entities would have been encouraged to be socially responsible and take care of the public interest. The global crisis has, however, shown the opposite. Radical deregulation of the market, as a principle of new classical theories, has not contributed to the stability of the economic system.

In anti-crisis economic policy, Keynesian discretion takes precedence over the fixed rules of new classical economists. It was shown that the rules limit the performance and success of monetary and fiscal authorities. On the other hand, discretionary rights enabled flexibility, which significantly affected the efficiency of economic policy instruments. As regards monetary policy, targeting a stable (low) inflation rate is important, but in a crisis it can prove extremely restrictive. Monetary authorities implemented discretionary measures, following both the Keynesian recommendation of low interest rates and the monetarists' focus on money supply. It seems that it is in this segment of economic policy that some agreement has been reached between theoretical extremes.

Anti-cyclical monetary policy measures were not sufficient for a faster recovery. The crisis has confirmed the utmost importance of anti-cyclical fiscal policy. The 
degree of expansiveness of fiscal policy largely depended on the pre-crisis budget position. Those governments that had had a responsible budgetary policy before the crisis were able to implement larger fiscal stimuli. Tax cuts with an increase in public expenditure and government investment were aimed at boosting GDP and employment. By analysing the structure and allocation of fiscal stimuli in the US, $\mathrm{EU}$ and China, it can be noted that the governments' intention was to stimulate (Keynesian) aggregate demand and launch important structural reforms through investments in long-term projects for the development of technology, entrepreneurship, education and energy efficiency.

However, when the recent economic crisis became global, doubts about the liberal concept transformed again into a renewed need for government intervention. There was a sudden reaffirmation of the Keynesian doctrine, as evidenced by measures of anti-cyclical monetary and fiscal policies in the world's leading economies. Keynesianism is back in a big way. The real question is: Is the return of Keynesianism a temporary need or a strategic imperative in any modern economy? Taking into account the current debate surrounding macroeconomics, there is no doubt that in order to succeed, a new macroeconomic paradigm or economic model of today must guarantee a more subtle control of the market by the state, especially when it comes to the financial system regulation. 


\section{References}

1. Angelovska Bezhoska, A. (2016). Central Bank Independence - the Case of the National Bank of Republic of Macedonia. Journal of Central Banking Theory and Practice, 6(3), 35-65.

2. Babić, M. (2007). Makroekonomija. Zagreb: Mate.

3. Blanchard, O. (2000). What Do We Know About Macroeconomics that Fisher and Wicksell Did Not? Quarterly Journal of Economics, 115(4), 13751409.

4. Broda, C., Parker, J. (2008). The Impact of the 2008 Tax Rebates on Consumer Spending: Preliminary Evidence. Chicago: University of Chicago.

5. Brunner, K., Meltzer, A. H. (1968). What Did We Learn from the Monetary Experience of the United States in the Great Depression? The Canadian Journal of Economics, 1(2), 334-348.

6. Cahill, D. (2011). Beyond Neoliberalism? Crisis and the Prospects for Progressive Alternatives. New Political Science, 33(4), 479-492.

7. Congdon, T. (2011). Milton Friedman on the Ineffectiveness of Fiscal Policy. Economic Affairs, Oxford: Blackwell Publishing, 62-65.

8. Custers, P. (2010). The Tasks of Keynesianism Today: Green New Deal As Transition Towards a Zero Growth Economy? New Political Science, 32(2), 173-191.

9. DeLong, J.B. (2002). Review of Skidelsky's John Maynard Keynes: Fighting for Britain. Journal of Economic Literature, 15, 155-162.

10. Dimitrijević, B., Fabris, N. (2009). Makroekonomija. Novi Sad: Univerzitet Educons.

11. Đurašković, J., Radović, M., Božović, Ž. (2016). Circularity of Economic Theories. Informatologia, 49(1-2), 9-21.

12. European Commission (2008). Communication from the Commission to the European Council, A European Economic Recovery Plan. Brussels: European Commission.

13. Goddard, J., Molyneux, P., Wilson, J. (2009). The financial crisis in Europe: evolution, policy responses and lessons for the future. Journal of Financial Regulation and Compliance, 17(4), 362-380.

14. Greenspan, A. (2010). The Crisis. Brookings Papers on Economic Activity, Brookings Institution Press, 201-246.

15. Herndon, T., Ash, M., Pollin, R. (2013). Does High Public Debt Consistently Stifle Economic Growth? A Critique of Reinhart and Rogoff. Political Economy Research Institute, Working Paper Series 322, 1-25.

16. HM Treasury (2008). Budget 2008 - Stability and Opportunity: Building a Strong, Sustainable Future, HC 388, London: The Stationery Office. 
17. International Labour Organization (2011). Studies on Growth with Equity, Germany: a job-centered approach. Geneva: IILS.

18. Jakšić, M., Jakšić, M. (2018). Inclusive Institutions for Sustainable Economic Development, Journal of Central Banking Theory and Practice, 7(1), 5-16.

19. Jakšić, M., Praščević, A. (2006). Makroekonomska analiza. Beograd: Centar za izdavačku delatnost Ekonomskog fakulteta u Beogradu.

20. Ješić, M. (2017). BOOK REVIEW: Monetary Policy, Inflation, and the Business Cycle: An Introduction to the New Keynesian Framework and its Applications, Princeton University Press, Second Edition, 2015, by Jordi Galí. Journal of Central Banking Theory and Practice, 6(1), 167-174.

21. Khasbulatov, R.I. (2015). Paradoxes of Economic Theories and Politics. Economy of Region, (2), 23-40.

22. Krugman, P. (2010). Povratak ekonomske depresije i svetska kriza 2008. Smederevo: Heliks.

23. Krugman, P. (2011). The Profession and the Crisis. Eastern Economic Journal, 37, 307-312.

24. Lawrence, H.W. (2009). Federal Reserve Policy and the Housing Bubble. Cato Journal, 29(1), 115-125.

25. Lucas, R.E.Jr. (2003). Macroeconomic Priorities. American Economic Review, 93(1), 1-14.

26. Meltzer, A. (2009). Reflections on the Financial Crisis. Cato Journal, 29(1), 25-30.

27. Meltzer, A. (2012). Federal Reserve Policy in the Great Recession. Cato Journal, 32(2), 255-263.

28. Reinhart, C., Rogoff, K. (2010). Growth in a Time of Debt. American Economic Review, Papers \& Proceedings 100, 573-578.

29. Sawyer, M. (2012). UK Fiscal Policy after the Global Financial Crisis. Contributions to Political Economy, 30, 13-29.

30. Schwartz, A. (2009). Origins of the Financial Market Crisis of 2008. Cato Journal, 29(1), 19-23.

31. Snowdon, B., Vane, H.R. (2006). Modern macroeconomics - Its Origins, Development and Current State. Cheltenham: Edward Elgar.

32. Štiblar, F. (2009). Uticaj globalne krize na Crnu Goru i Zapadni Balkan. Podgorica: Centralna banka Crne Gore.

33. Stiglitz, J. E. (2009). The Current Economic Crisis and Lessons for Economic Theory. Eastern Economic Journal, 35, 281-296.

34. Stiglitz, J.E. (2010). Lessons from the Global Financial Crisis of 2008. Seoul Journal of Economics, 23(3), 321-339.

35. The Central Bank of the Russian Federation (2010). Annual Report 2009. Moscow: TASS. 
36. The Guardian: Greenspan - I was wrong about the economy, availible at: https://www.theguardian.com/business/2008/oct/24/economicscreditcrunch-federal-reserve-greenspan, referred on 02/02/2018.

37. The People's Bank of China, available at, http://www.pbc.gov.cn/history_file/ files/att_20485_2.pdf, referred on 20/05/2013.

38. Thomas, L.B. (2011). The Financial Crisis and Federal Reserve Policy. New York: Palgrave Macmillan.

39. Vollmer, U., Bebenroth, R. (2012). The Financial Crisis in Japan: Causes and Policy Reactions by the Bank of Japan. The European Journal of Comparative Economics, 9(1), 51-77.

40. Wong, C. (2011). The Fiscal Stimulus Programme and Public Governance Issues in China. OECD Journal on Budgeting, 3, 53-73. 